\title{
An Outline of Meat Consumption in the Indian Population - A Pilot Review
}

\author{
Subramaniam Mohana Devi, Vellingiri Balachandar ${ }^{1}$, Sang In Lee ${ }^{2}$, and In Ho Kim* \\ Department of Animal Resource \& Science, Dankook University, Cheonan 330-714, Korea \\ ${ }^{1}$ Human Molecular Genetics Laboratory, Department of Zoology, Bharathiar University, Coimbatore - 641 046, India \\ ${ }^{2}$ Animal Biotechnology Division, National Institute of Animal Science, RDA, Suwon 441-706, Korea
}

\begin{abstract}
The consumption of meat is increasing in India and agriculture is considered as the backbone of a majority of people. Livestock plays a significant role, and poultry and dairy are the major sectors contributing to economic development. The majority of meats consumed in India are fish, bovine, mutton, goat, pig, and poultry. In Indian context, culture, traditions, customs, and taboos influence meat consumption to a great extent. However, studies show that urbanization has been causing a rise in demand for meat products. India is the world's second largest exporter of beef. In India, 95\% of goat meat produced is consumed locally. Meat consumption, in particular, is determined by the religions where pork is forbidden to Muslims and beef is prohibited to Hindus. The preference and consumption of chicken meat can be considered as a universal phenomenon and chicken meat is greatly accepted by consumers in India as compared to the other meat consumption. The increase of chicken meat consumption is due to the versatility of the meat, relatively low cost in comparison to other meat, and the acceptance of the chicken meat to all religions. There has been a great rise in the production of livestock products and this is expected to continue in the future. The pattern of meat consumption depends considerably on culture, tradition and urbanization. This review was formulated with the objective of identifying the meat consumption patterns in a typical Indian society.
\end{abstract}

Keywords: meat, India, consumption

\section{Introduction}

Agriculture is a major force driving the environment beyond the boundaries (Rockstrom et al., 2009). Of all activities humans engage on Earth, meat consumption has the largest environmental impact ranging from local to global. In India, growth in agricultural productivity has been slow during the past two decades, and demand is growing for poultry and dairy products, in addition to traditional staples, fruits, and vegetables. India remains home to the highest number of food-insecure people (Charles, 2012). Increase in meat production and it's demand is expected to take place mainly in developing countries. Between 1995 and 2020 they will account for almost 85 percent of the increase in global demand as against 25 percent in developed countries (IFPRI, 1999). Over the past 50 years, meat consumption in particular has chan-

\footnotetext{
*Corresponding author: In Ho Kim, Department of Animal Resource \& Science, Dankook University, Cheonan 330-714, Korea. Tel: +82-41-550-3652, Fax: +82-41-565-2949, E-mail: inhokim@dankook.ac.kr
}

ged dramatically. Human diet and nutritional status have undergone a sequence of major shifts, stated as the nutrition transition (Popkin, 2006; Tey et al., 2010).

According Dietz et al. (1996), patterns of food production and consumption are at the core of all human ecology. Evidence for hominid and early human omnivore is rich and indisputable (Kiple, 2000; Larsen, 2000; Stanford and Bunn, 2001; Wing, 2000). Global meat including beef, pork and poultry exports have grown over $40 \%$ in less than 10 years, of 2014 forecast, depicting a strong demand and a record on rising incomes (Fig. 1). Beef and broiler meat are likely to reach a new record and pork to nearer level. For broiler meat, the growth continues from the Middle Eastern and Sub- Saharan African regions and it is expanding at a faster rate (USDA, 2013).

Among animal foods, meat is considered as highly nutritious and has become an integral component of human diet being a rich source of valuable proteins, vitamins, minerals, micronutrients and fats. Meat consumption is supposed to supply omega 3 fatty acid and conjugated linoleic acid that affords multifaceted nutrient for human health. The style of cooking meat in India is different 


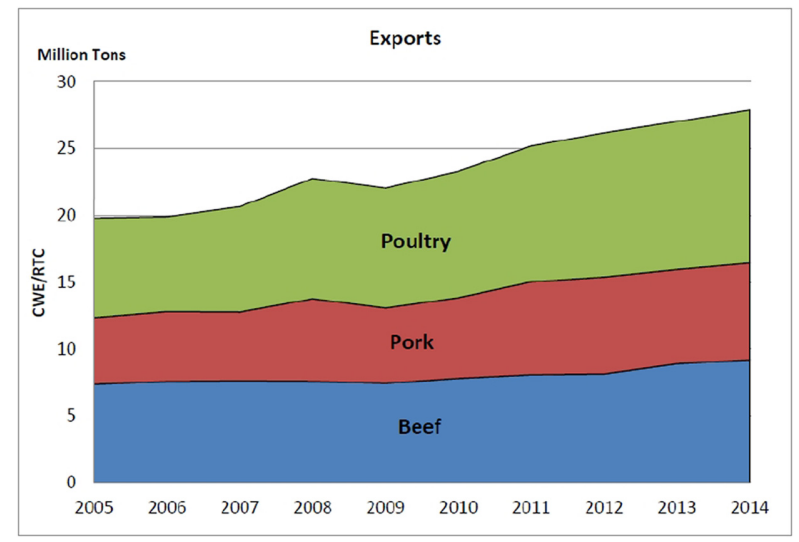

Fig. 1. Record of global meat trade (Source: USDA, 2013).

from that of other countries due to the incorporation of more spices, chilies in their preparations. The majority of meats consumed in India are fish, bovine (cow and buffalo), mutton, goat, pig, and poultry.

Meat-related development of major evolutionary importance was the domestication of many animal species that began about 11,000 years ago with sheep and goats and then progressed to cattle, pigs, horses, and camels (Alvard and Kuznar, 2001). In North East India livestock accounts for $18 \%$ of the value of output from the agriculture sector (Kumar et al., 2007). Since in early 1990s, India has achieved a striking speed of economic growth, leading to increased disposable income of Indian consumers. It would have been expected that income growth would lead to changes in the structure of demand for food commodities in India. However, research concerning India's food consumption continues to be focused on foods from plants, while the demands for foods of animal origin are poorly understood. In India, there is only limited number of earlier studies that looked into animal resource consumption. These include studies of Sinha and Giri (1989), examining the consumption of livestock products for three states of Gujarat, Punjab and Tripura (Gandhi and Mani, 1995), discussed about the importance of livestock product demand in India till the late 1980s and Dastagiri (2004), provided some general features of livestock product demand using data up to 1993. However, no previous studies have well pictured the consumption of animal products. An evaluation of India's animal product consumption with the latest available data is necessary. This review focuses on meat consumption in India because of its particularly serious effects on the global environment. With this background, the present review was formulated with the objective to identify the meat consumption patterns in a typical Indian society.

\section{Factors Influencing Meat Consumption}

In developing countries, culture plays a crucial role in determining food patterns (Lahsaeizadeh, 2001). As Indians are controlled by the traditions and customs, thus the dietary habit is significantly influenced. In Indian context, culture, traditions, customs, and taboos influence meat consumption to a great extent especially in the rural societies. However, studies show urbanization has been causing a rise in demand for meat products. As people move to cities, they adapt to get into meat consumption. The difference in consumption and production methods correlates strongly with the overall economy of a country. India is the country that consumes the least meat per capita (Tepper, 2012). In India, cultural differences are also accountable for variations in meat consumption patterns. In the case of India, the Hindu tradition of non-violence is the major reason for why the country does not consume large amounts of meat (Hindu ethic of nonviolence, 1996). Differences in food consumption exist across regions and states. India's north and western region people are mainly wheat consumers, while in the south are mainly rice consumers (Gandhi and Koshy, 2006). There is also a vast variation in the per capita consumption of livestock products across states and regions (Gandhi and Zhou, 2010).

In India, meat consumption is still below $5 \mathrm{~kg} / \mathrm{cap} /$ year (FAO, 2012). Almost one third of Indians follow lactovegetarianism which came into prominence during the rule of Emperor Ashoka of the Maurya Empire, a promoter of Buddhism (Thakrar, 2007). Vegetarianism is much less common amongst Sikhs, Muslims, Christians, Bahais, Parsis and Jews (Yadav et al., 2006). Hinduism bars beef consumption, whilst Islam bars pork. Indian people ascribe greater cognitive functions to animals that they perceive to be alike to themselves (Epley et al., 2008), and omnivores attribute considerably fewer mental and emotional complexity to animals (Bilewicz et al., 2011). Thus the meat consumption habits of people in the state depend considerably on culture, tradition, urbanization etc, among others. Agrahar and Pal (2005) studied that, the food consumption pattern of Khasi tribals in 13 tribal villages in Meghalaya, India, and reported that their dietary pattern was still traditional. Rice, meat, roots and tubers, fermented foods, green leafy vegetables and fruits were consumed every day.

According to UNFAO (2007), Indians had the lowest rate of meat consumption. Most restaurants in India clearly distinguish "Vegetarian" and "Non-vegetarian". India has given a system of marking edible products made from 

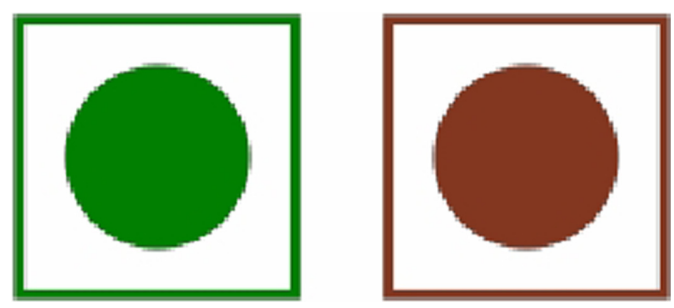

Fig. 2. Indian system of marking edible products. Vegetarian (Green) and Non-Vegetarian mark (Brown).

vegetarian ingredients with a green dot in green square (Fig. 2) and animal based products with a brown dot in brown square. According to the state national survey by Hindu-CNN-IBN, $31 \%$ are vegetarians, $9 \%$ consume egg mainly due to the $55 \%$ Brahmin communities were vegetarians whereas vegetarianism is less frequent among Muslims (3\%) and residents of coastal areas. Other surveys conducted by FAO and USDA estimates that 20 to $42 \%$ of Indians are being vegetarian.

\section{Consumption of Meat}

Food consumption is a basic action contributing to survival of human beings. Therefore, the understanding of the food culture creates a better understanding and more intimate relationship among countries and people (Koo et al., 2008). The improvement in agriculture, allowed some fundamental changes in the human way of life. Animal derived food goods are the most resource intensive foods (Chemnitz and Becheva, 2014; Connor and Mínguez, 2012; Marlow et al., 2009; Science News, 2010). Animal protein foods are at the top of the food chain in relation to the resources (Chemnitz and Becheva, 2014). In many developing nations, it is expected that global meat consumption will continue to rise (Buttriss, 2011; Connor and Mínguez, 2012). Fiala (2008) has suggested that if meat consumption patterns continue along the same path, then the consumption rates will be $72 \%$ higher than 2000 levels in the year 2030. Demand for meat is growing in rapidly developing countries, particularly India, China and Brazil (Cheminitz and Becheva, 2014; OECD, 2011)

Since the 1970s, there was a reduction in intake of whole grain cereals, pulses, fruits and vegetables in India while intake of meat products have been increased (Misra et al., 2011; Popkin, 2002; Popkin et al., 2012). Animal Husbandry is playing a pivotal role in the Indian economy by contributing by about $5.5 \%$ of Indian GDP (Gross Domestic Product) (Basic Animal Husbandry Statistics 2002). Therefore, average annual per capita meat supply (in carcass weight) remains below $5 \mathrm{~kg}$ in India (FAO, 2002). Due to taboos against the slaughter and consumption of cattle, beef consumption is banned in India, with the notable exceptions of the states of Kerala and West Bengal, as well as a few northeastern states. Chicken is India's preferred non-vegetarian protein source, with local production increasing by an estimated 10 percent annually. Given Indian meat preferences, domestic consumption is not expected to exceed the rate of population growth. 2012 consumption is estimated to have increased marginally, by 1.7 percent to 2.01 million metric tons. 2013 consumption is forecast at 2.05 million metric tons, a 1.9 percent increase. The meat consumption patterns of rural people of Prakasam district of Andhra Pradesh, India revealed that the most preferred meat was chicken (50.0\%), followed by mutton (25.0\%) and fish $(25.0 \%)$ (Thammi Raju and Suryanarayana, 2005). Picture 6, depicts the culture of food consumption in India with different recipes.

Food balance sheets illustrate levels below $5 \mathrm{~kg} /$ year until the late 1980s (FAO 2002). Milk, meat, and egg consumption in India is rising much faster than that of cereals (Table 1). Nearly $37 \%$ of agricultural output growth between 2005 and 2011 came from animal products. Within this category, output of eggs and meat has risen faster, and poultry the fastest. Animal products have also contributed to $33 \%$ of the incremental food inflation over the past five years (Fig. 3). Strong demand for dairy products encourages continued expansion in the bovine

Table 1. Per capita consumption of meats: quantity and value per month, 2004/05

\begin{tabular}{ccccccc}
\hline \hline \multirow{2}{*}{ Item } & \multicolumn{2}{c}{ Rural } & \multicolumn{2}{c}{ Urban } & ALL \\
\cline { 2 - 7 } & Quantity $\left(\mathrm{Kg}^{*}\right)$ & Value (Rs) & Quantity (Kg*) & Value (Rs) & Quantity (Kg*) & Value (Rs) \\
\hline Goat meat/ Mutton & 0.047 & 4.31 & 0.070 & 7.85 & 0.053 & 5.21 \\
Beef/ buffalo meat & 0.031 & 1.34 & 0.056 & 2.26 & 0.037 & 1.57 \\
Pork & 0.006 & 0.40 & 0.005 & 0.29 & 0.006 & 0.37 \\
Chicken & 0.050 & 3.14 & 0.085 & 5.49 & 0.059 & 3.73 \\
Others meats & 0.003 & 0.11 & 0.002 & 0.06 & 0.003 & 0.10 \\
\hline Meat total & 0.137 & 9.30 & 0.218 & 15.95 & 0.158 & 10.98 \\
\hline
\end{tabular}

Source: NSSO 2007, $61^{\text {st }}$ Round. 


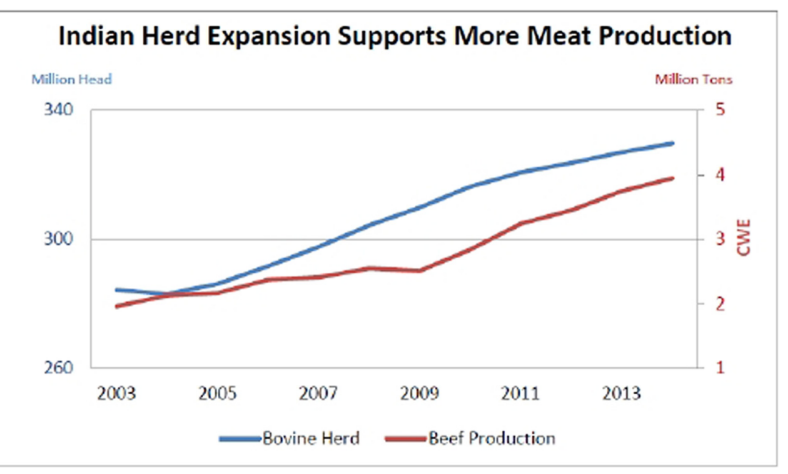

Fig. 3. Indian herd expansion supports meat production. Source: United States Department of Agriculture Foreign Agricultural Service Approved by the World Agricultural Outlook Board/USDA November 2013.

herd (USDA, 2013).

\section{Different Kinds of Meat Consumption}

\section{Beef}

According to data compiled by the animal husbandry departments of all states, meat from registered slaughter houses increased from 5.57 lakh tonnes in 2008 to 8.05 lakh tonnes in 2011. Export earnings from bovine (beef and cattle) meat expected to touch Rs. 18,000 crore in 2012-2013 with about $70 \%$ of the buffalo meat exported. According to the US Department of Agriculture, India became the largest exporter of beef edging out Australia and New Zealand in May 2012 (The Times of India, 2013). Picture 1 shows the beef meat for sale in India.

\section{Goat}

Goats constitute an important species of livestock in Asia and contribute greatly to food, rural employment and Gross Domestic Product. Goat meat is relished in all countries of Asia, Africa and Middle East where there is a tradition for meat consumption from both sheep and goats, and in some countries, such as plains of India, the goat is the major supplier of meat. Goat rising is one of the important agricultural enterprises particularly in rural parts. Picture 2 shows the goat meat for sale in India. In India, $95 \%$ of goat meat produced is consumed locally and the per capita availability is far below the requirement. Thus, there is a considerable potential for developing goat production not only for meat for internal consumption but also for export, for quality leather production in which India ranks high among the goat skin exporting countries.

Goat meat is consumed in more than 40 countries viz.
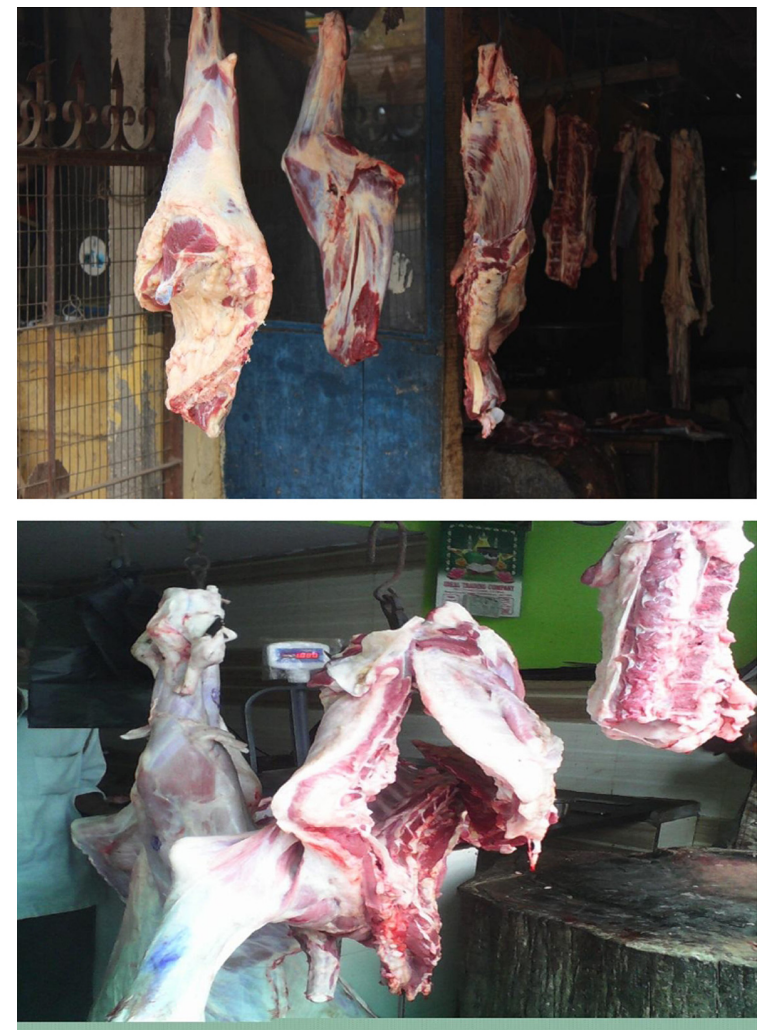

Picture 1. Pictures of different kinds of meat for sale in India: Beef meat.
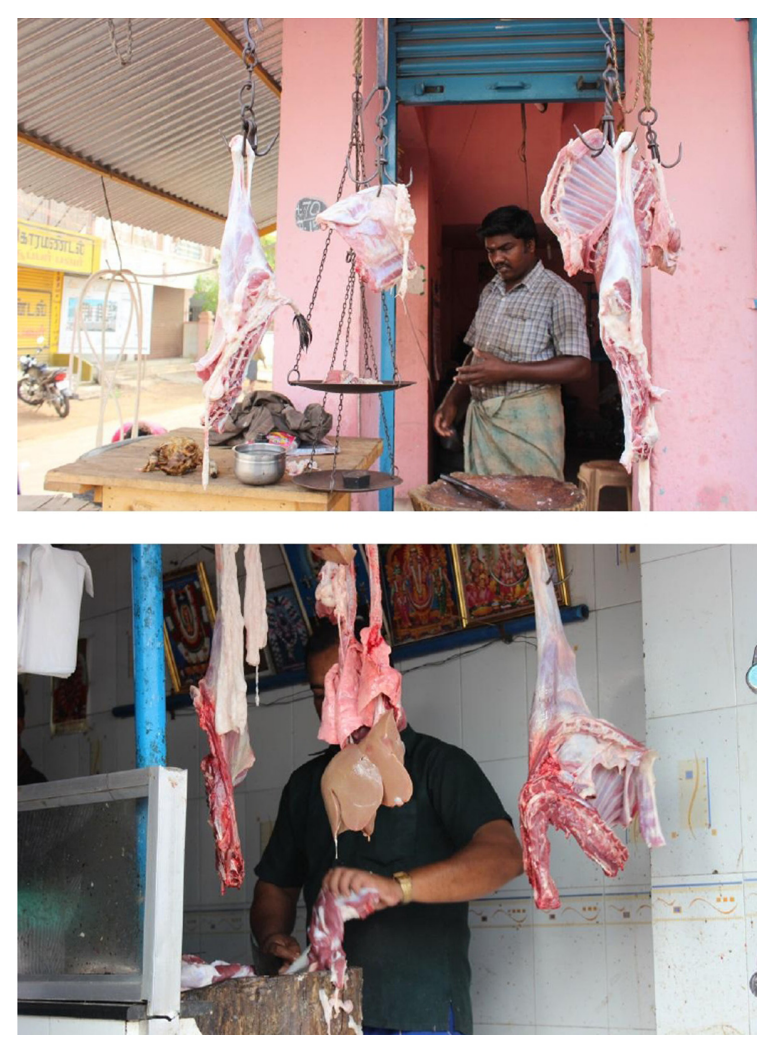

Picture 2. Pictures of different kinds of meat for sale in India: Goat meat. 
Australia, Canada, Caribbean Islands, China, Dubai, Greece, Hong Kong, India, Italy, Japan, Malaysia, Mauritius, Mexico, New Zealand, Pakistan, Papua New Guinea, Portugal, Saudi Arabia, Singapore, South Africa, South Korea, Switzerland, Taiwan, United States of America, Venezuela, Vietnam, / Argentina, France, Germany, Ireland, Spain, United Kingdom, Bulgaria, Poland, Romania, Republic of Kazakhstan, Russian Federation, Ukraine, Turkey and Egypt (Pinkerton, 1995). India having the second largest goat population in the World can play a vital role to exploit this market. Asia has the largest population of goats with $55 \%$ of world goat population, mostly in India (35.2\%), China (29.3\%) and Pakistan (12\%) (Devendra, 2006). China has the highest consumption of goat meat, followed by India and Pakistan (Food and Agriculture Organisation, 2009). Goats of different ages can be used for human consumption (Devendra and Owen, 1983) and the younger animals were slaughtered at 8-12 wk or with $6-8 \mathrm{~kg}$ and the adult at 2 and 6 years of age weighing 20-30 kg).

\section{Pork}

In India, the traditional system of rearing pigs has not been well characterized. In Sikkim, amongst livestock, pigs are the most important, and every tribal family rears pigs as a backyard venture. There is a huge demand for pigs because people of this state prefer pork than other meats. According to Ajala et al. (2007), in India, over $70 \%$ of people depend on agriculture and livestock for their livelihood. The income from pigs accounts for about $50 \%$ of total family income in the remote areas of the northeast region of India. In North-East India, most of the pigs were reared in intensive system and fed with homemade cooked feed (kitchen waste and locally available plants) (Kumaresan et al., 2009). Moanaro et al. (2011) reported pig rearing under a low-input production system in the Nagaland State of India where nonconventional feed resources give majority of the feedstuffs offered to the animals. Picture 3 shows the pork meat for sale in India.

\section{Fish}

The nutritive value of fish is determined by the content of fatty acids that are beneficial to health. Traditionally, India has displayed a strong preference for ovine and caprine meat and fish in different geographical segments of the country. The high consumer retail price and low availability of chicken meat in the early 1990s contributed largely to this trend. However, with increased pro-
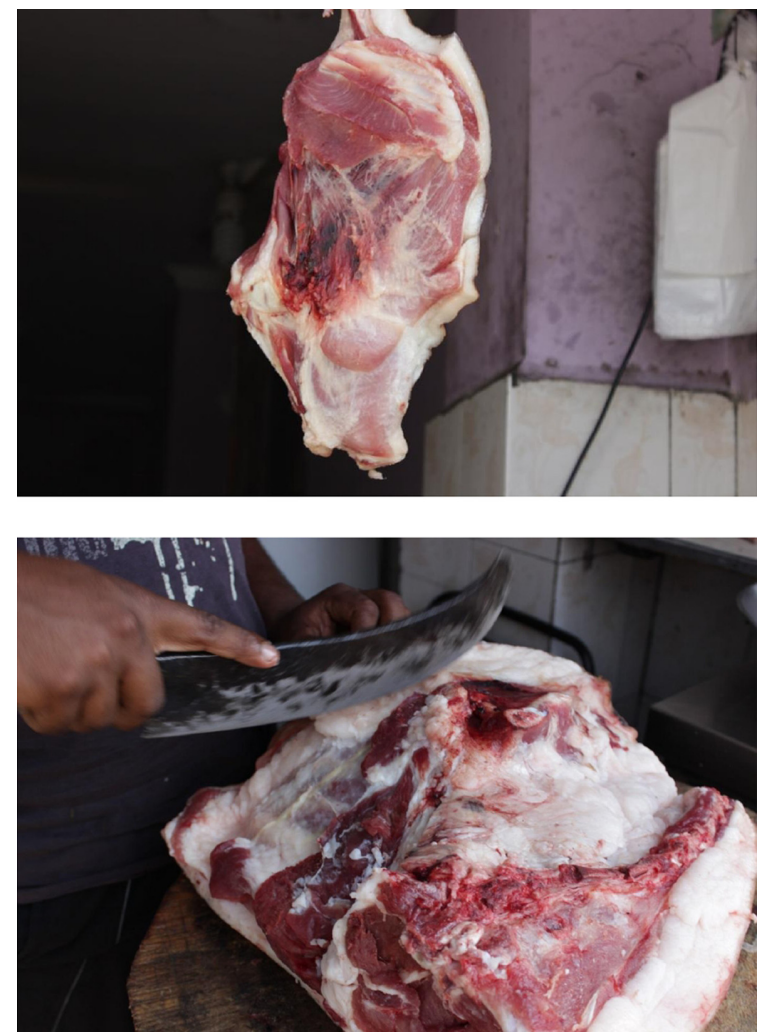

Picture 3. Pictures of different kinds of meat for sale in India: Pork meat.
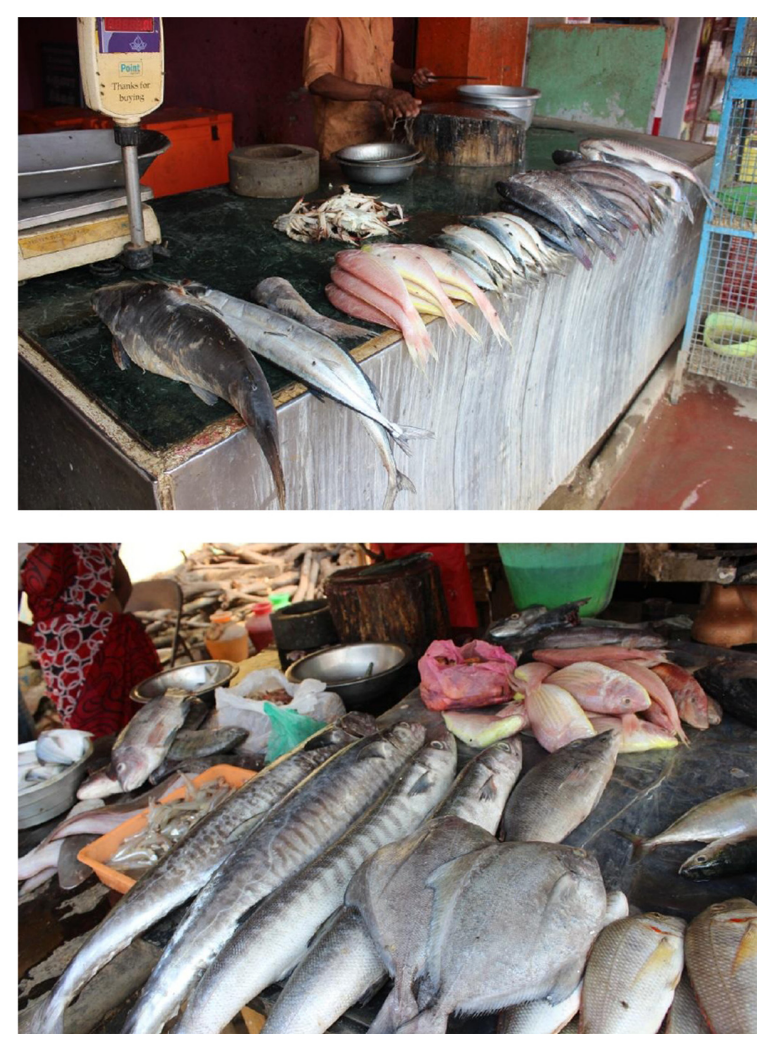

Picture 4. Pictures of different kinds of meat for sale in India: Fish meat. 
Table 2. India's poultry meat consumption

\begin{tabular}{cccccc}
\hline \hline & 2010 & 2011 & 2012 & 2013 & 2014 \\
\hline Per Capita (Kg) & 1.9 & 2.0 & 2.1 & 2.2 & 2.2 \\
Total in Kilotons & $2,645.9$ & $2,889.6$ & $3,062.1$ & $3,154.7$ & $3,246.8$ \\
\hline
\end{tabular}

Source: http://www.oecd.org/site/oecd-faoagriculturaloutlook/

duction efficiency and greater market penetration, this trend has shown a radical change (CLFMA, 2005). Picture 4 shows the fish meat for sale in India. Fish are an important source of protein for humans. Additionally, they are low in cholesterol and contain beneficial polyunsaturated fatty acids (Ersoy and Celik, 2010). Even though India occupies fourth position in terms of fish production, the per capita consumption of fish in India is only $4.8 \mathrm{~kg} /$ year (http://www.st.nmfs.gov/st1/fus/us04/08 perita2004.pdf). India exports shrimp and fish to the world market and majority of the population along the coastal regions consume fish.

\section{Poultry}

Meat consumption in particular is determined by the religions where pork is forbidden to Muslims and beef is prohibited to Hindus, which makes poultry meat highly consumed due to its religious acceptance. This is due to the increased demand from consumers with higher incomes and the perceptions that poultry meat is healthier than other meats. Red meat consumption in India is very low, for cultural and religious reasons. But India has contributed in the global Livestock Revolution through extraordinary growth in the consumption of milk, eggs, and poultry meat. Poultry is in fact one of the fastest growing segments of the agricultural sector in India today (Table 2). Broiler meat production is forecast to rise $6 \%$ to 3.6 million tons in 2014, fueled by escalating demand for animal protein and a rising preference for processed poultry products, an indication of changing tastes and preferences (Fig. 4). Chicken meat production in India was ranked 6th in the world in 2011, using FAOSTAT rankings. (Source: Foreign Agricultural Service, Official USDA Estimates). India's per capita consumption of poultry meat is forecast at $2.2 \mathrm{~kg}$ per annum in 2014; chicken is India's preferred non-vegetarian protein source. Gandhi and Zhou (2010) indicated a rapid rise demand for animal products in India. Milk demand may grow at about $10.6 \%$ per year, egg demand at $7.4 \%$ and meat demand at $8.4 \%$. Except for chicken in which production growth somewhat exceeds the demand growth. A recent study projects India's meat consumption (mostly poultry meat) rising to $18 \mathrm{~kg}$ in 2050 (Van der Mensbrugghe et al., 2011). Even so, India will

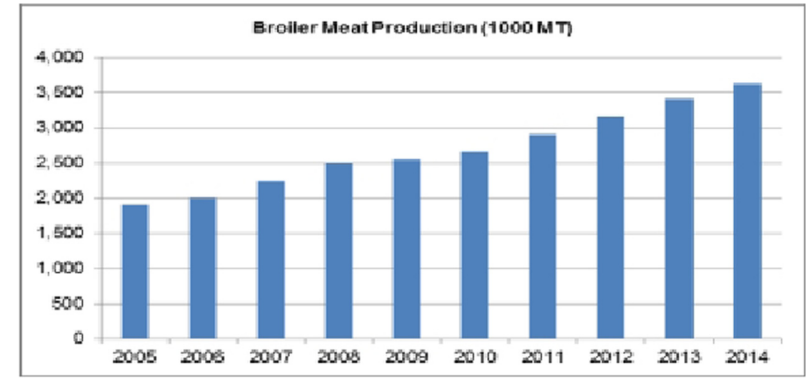

Fig. 4. Broiler meat production in India. Source: Foreign Agricultural Service, Official USDA Estimates.
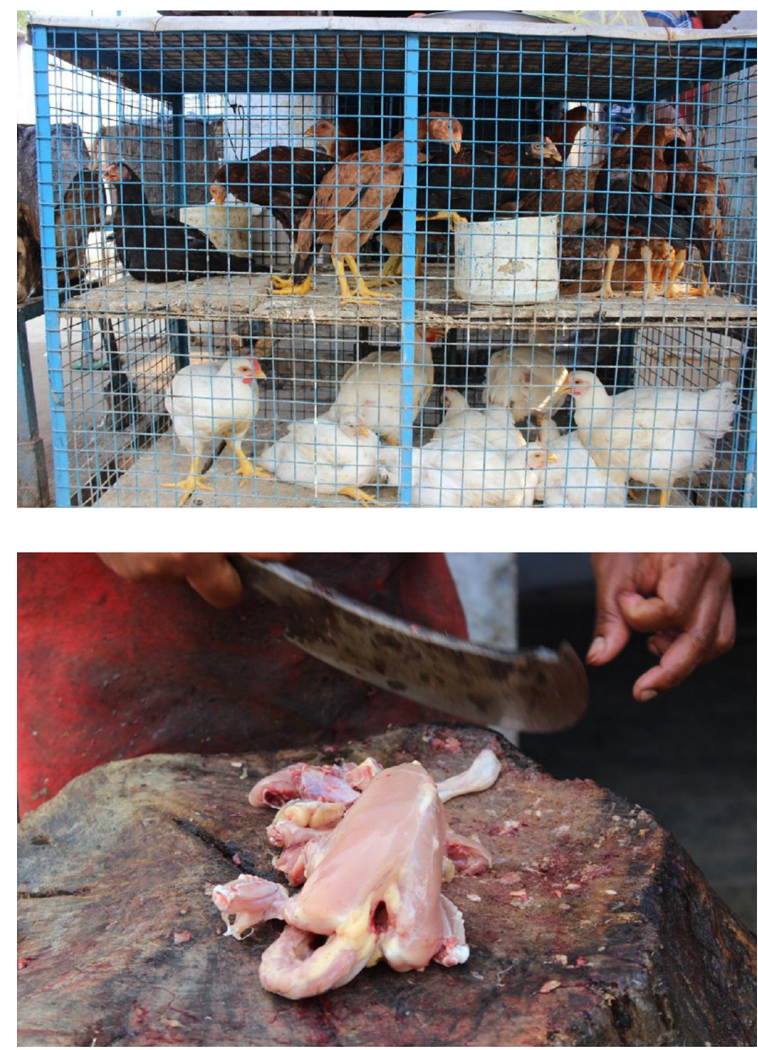

Picture 5. Pictures of different kinds of meat for sale in India: Poultry meat.

still have very low meat consumption compared with other countries.

The preference and consumption of chicken meat can be considered as a universal phenomenon and chicken meat is greatly accepted by consumers worldwide as 
compared to the other meat consumption. The increase of chicken meat consumption is due to the versatility of the meat, relatively low cost in comparison to other meat, the acceptance of the chicken meat to all religions and increase in the household income. Other countries suggest that India is an internationally competitive producer of poultry meat. According to Rao et al. (2005), chicken meat is also served during Christmas festival and one of the unique dishes served in India during this season is chicken Manchuria. As far as the Indians are concerned, they prefer salad as a side dish for chicken meat (Jayaraman et al., 2013). Picture 5 shows the poultry meat for sale in India.
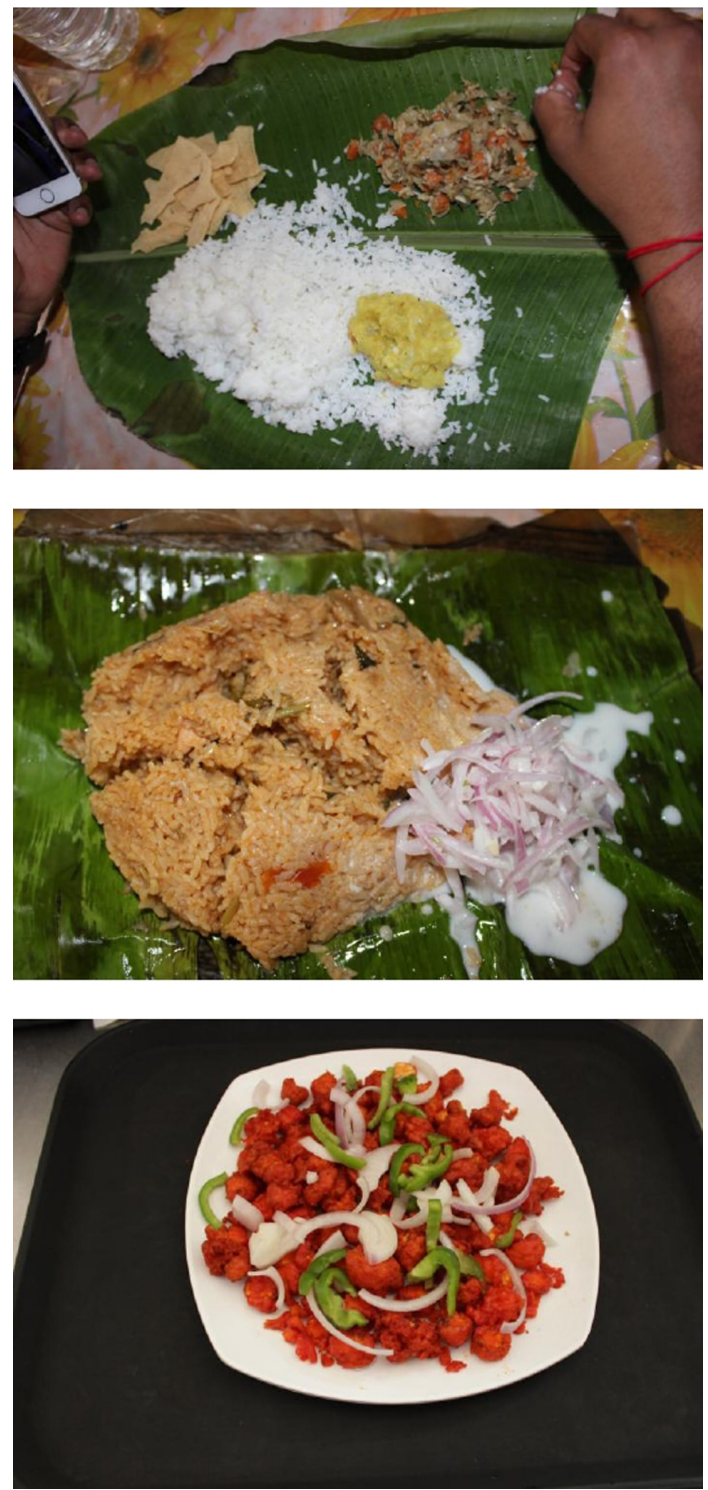

Picture 6. Different kinds of food consumption pattern in India. (a) Vegetarian food - Rice with vegetable curries.

\section{Conclusion}

Traditionally, people in India eat foods based on grains and vegetables, and consume limited amounts of meats and meat products. The recent economic growth and introduction of western culture have changed the food consumption habits in India. The increase of the consumption of meat and meat products, however, will be limited, because of the staple diet due to the climate, geography, religion, and food culture. In order to increase meat consumption, a stable investment should be a prerequisite from the government.

There has been a great rise in the production of livestock products and this is expected to continue in the
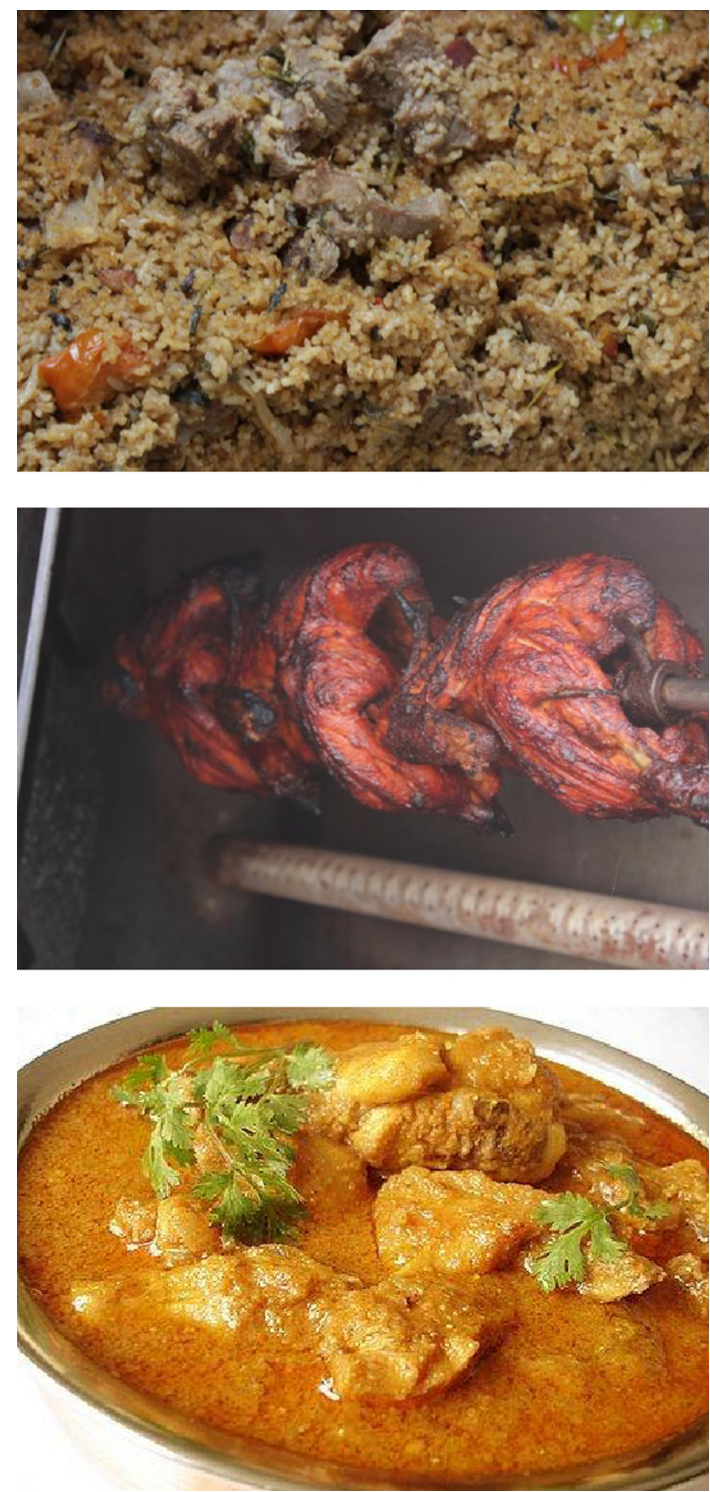

Picture 6. Different kinds of food consumption pattern in India. (b) Non-Vegetarian food - Biryani (Rice with goat meat), grilled chicken and chicken spicy gravy. 
future. This is particularly the case in developing countries like India. Although there is overconsumption of meat in developed regions, there is clearly a need to promote the development of livestock production and the consumption. Livestock production can make good use of resources, some of which would otherwise not be used, and contributes high quality protein and important micronutrients to the human diet. The pattern of meat consumption in India depends considerably on culture, tradition and urbanization.

\section{Reference}

1. Agrahar, M. D. and Pal, P. P. (2005) Food consumption pattern of the tribals of Meghalaya and its relation with socioeconomic factors. Ind. J. Nutr. Diet. 42, 71-80.

2. Ajala, M. K., Adesehinwa, A. O. K., and Mohammed, A. K. (2007) Characteristics of smallholder pig production in Southern Kaduna area of Kaduna state, Nigeria. Amer-Eurasian. J. Agri. Environ. Sci. 2, 182-187.

3. Alvard, M. S. and Kuznar, L. (2001) Deferred harvests: The transition from hunting to animal husbandry. American Anthropologist 103, 295-311.

4. Basic Animal Husbandry Statistics (2002) Government of India, Ministry of Animal Husbandry and Dairying, Krishi Bhavan, New Delhi.

5. Bilewicz, M., Imhoff, R., and Drogosz, M. (2011) The humanity of what we eat. Conceptions of human uniqueness among vegetarians and omnivores. European J. Social Psychol. 41, 201-209.

6. Buttriss, J. L. (2011) Feeding the planet: an unprecedented confluence of pressures anticipated. Nutrition Bulletin 36, 235-241.

7. Charles, D. (2012) The making of meat eating America. WNYC, 26 June 2012, http://culture.wnyc.org

8. Chemnitz, C. and Becheva, S. (2014) Meat Atlas 2014. Retrieved 24 February 2014 from: www.foeeurope.org/meatatlas

9. CLFMA (2005) Poultry Meat Industry. Livestock Industry Report 2005. Compound Livestock Feed Manufacturers Association of India. 2005.

10. Connor, D. J. and Mínguez, M. I. (2012) Evolution not revolution of farming systems will best feed and green the world. Global Food Security 1, 106-113.

11. Dastagiri, M. B. (2004) 'Demand and supply projections for livestock products in India', Policy Paper 21, National Centre for Agricultural Economics and Policy Research (NCAP), ICAR, New Delhi, India.

12. Devendra, C. and Owen, J. E. (1983) Quantitative and qualitative aspects of meat production from goats. World Anim. Rev. 47, 19-29.

13. Dietz, T., Kalof, L., and Frisch, A. S. (1996) The human ecology of the vegetarian diet: A bibliography. Hum. Eco. Revi. 2, 181-186.
14. Epley, N., Waytz, A., Akalis, S., and Cacioppo, J. T. (2008) When we need a human. Motivational determinants of anthromorphism. Social Cognition 26, 143-155.

15. Ersoy, B. and Celik, M. (2010) The essential and toxic elements in tissues of six commercial demersal fish from Eastern Mediterranean Sea. Food Chem. Toxicol. 48, 1377-1382.

16. Fiala, N. (2008) Meeting the demand: an estimation of potential future greenhouse gas emissions form meat production. Ecol. Econ. 67, 412-419.

17. Food and Agriculture Organization (FAO) (2000) The State of Food Insecurity in the World 2000. Rome: FAO. http:// www.fao.org/DOCREP/X8200/X8200E00.HTM/2002. FAOSTAT Agriculture Database. http://apps.fao.org

18. Food and Agriculture Organization (FAO) (2002) Available from: http://www.oecd.org/site/oecd-faoagriculturaloutlook/

19. Food and Agriculture Organization (FAO) (2009) Agriculture production domain. Retrieved from http://faostat.fao.org/site/ 339/default.aspx

20. Gandhi V. P. and Koshy, A. (2006) Wheat marketing and its efficiency in India. Working paper No. 2006-09-03. Ahmedabad, India: Indian Institute of Management.

21. Gandhi, V. P. and Mani, G. (1995) Are livestock products rising in importance? A study of the growth and behaviour of their consumption in India, Indian J. Agri. Economics 50, 283-293.

22. Gandhi V. P. and Zhou, Z. Y. (2010) Rising demand for livestock products in India: Nature, patterns and implications. Australasian Agribusiness Review 18, 103-135.

23. Hindu ethic of nonviolence, Hinduism today, February (1996) http://www.hinduismtoday.com

24. IFPRI (1999) World Food Prospects: Critical issues for the early $21^{51}$ century. Food Policy Statement 29.

25. Jayaraman, K., Munira, H., Dababrata, C., and Iranmanesh, M. (2013) The preference and consumption of chicken lovers with race as a moderator - An empirical study in Malaysia. Inter. Food Res. J. 20, 165-174.

26. Kiple, K. F. (2000) "The question of Paleolithic nutrition and modern diet" in Kiple, K. F. and Ornelas, K. C. (eds.), The Cambridge World History of Food. Cambridge: Cambridge University Press, pp. 1704-1709.

27. Koo, N. S., Kwon, S. J., Lee, K. A., and Ly, S. Y. (2008) Food and culture in the world (pp. 111). Paju: Kyomoonsa.

28. Kumar, A., Staal, S., Elumalai, K., and Singh, D. K. (2007) Livestock sector in northeastern region of India: an appraisal of performance. Agri. Eco. Resort Reviews 20, 255-272.

29. Kumaresan, A., Bujarbaruah, K. M., Pathak, K. A., Das, A., and Bardoloi, R. K. (2009) Integrated resource-driven pig production systems in a mountainous area of Northeast India: production practices and pig performance. Trop. Anim. Health Prod. 41, 1187-1196.

30. Lahsaeizadeh, A. (2001) Social analysis of food and nutrition in Iran. Nutr. Food Sci. 31, 129-135.

31. Larsen, C. S. (2000) "Dietary reconstruction and nutritional assessment of past peoples. The bioanthropological record," in Kiple, K. F., and Ornelas, K. C., (eds.), The Cambridge World History of Food. Cambridge, Cambridge University 
Press, pp. 13-34.

32. Marlow, L. J., Hayes, W. K., Soret, S., Carter, R. L., Schwab, E. R., and Sabate, J. (2009) Diet and the environment: does what you eat matter? Am. J. Clin. Nutr. 89, 1699S-1703S.

33. Misra, A., Singhal, N., Sivakumar, B., Bhagat, N., Jaiswal, A., and Khurana, L. (2011) Nutrition transition in India: secular trends in dietary intake and their relationship to diet-related non-communicable diseases. J. Diabetes 3, 278-292.

34. Moanaro, Ngullie, E., Walling, I., Krose, M., and Bhatt, B. P. (2011) Traditional Animal Husbandry Practices in Tribal States of Eastern Himalaya, India: A Case Study. Indian J. Anim. Nutr. 28, 23-28.

35. National Sample Survey Organization (NSSO) (2007) Household Consumption of Various Goods and Services in India, 2004-05, Report no. 509, Vol. 1 \& 2, Ministry of Statistics.

36. OECD (2011) OECD-FAO Agricultural Outlook 2011. OECD Publishing.

37. Pinkerton, F. (1995) Meat Goat Marketing in Greater New York City. The Center for Agricultural Development and Entrepreneurship, State University of New York, Oneonta.

38. Popkin, B. M. (2002) An overview on the nutrition transition and its health implications: the Bellagio meeting. Pub. Health Nutr. 5, 93-103.

39. Popkin, B. M. (2006) Global nutrition dynamics: the world is shifting rapidly toward a diet linked with noncommunicable diseases. Am. J. Clin. Nutr. 84, 289-298.

40. Popkin, B. M., Adair, L. S., and Ng, S. W. (2012) Global nutrition transition and the pandemic of obesity in developing countries. Nutr. Reviews 70, 3-21.

41. Rao, P., Ramesh, B. V., Sudershan, R. V., and Krishna, P. T. (2005) Consumption of synthetic food colours during festivals in Hyderabad, India. British Food J. 107, 276-284.

42. Rockstrom, J., Steffen, W., Noone, K., Persson, A., Chapin III, F., Lambin, E., Lenton, T., Scheffer, M., Folke, C., Schellnhuber, H., Nykvist, B., de Wit, C., Hughes, T., van der Leeuw, S., Rodhe, H., Sorlin, S., Snyder, P., Costanza, R., Svedin, U., Falkenmark, M., Karlberg, L., Corell, R., Fabry, V., Hansen, J., Walker, B., Liverman, D., Richardson, K., Crutzen, P., and Foley, J. (2009) A safe operating space for humanity. Nature 461, 472-475.

43. Science News (2010) Agriculture, food production among worst environmental offenders, report finds. Retrieved 10 October 2013 from http://www.sciencedaily.com/releases/
2010/06/100609094353

44. Sinha, P. and Giri, A. K. (1989) Consumption of livestock products - analysis and comparison of data of NSS 32nd NSS 38th Round, in Indian Society of Agricultural Economics (1989). Livestock Economy of India, Oxford and IBH Publishing Co. Pvt. Ltd., New Delhi.

45. Stanford, C. and Bunn, H. T. (eds.) (2001) Meat-Eating and Human Evolution. New York: Oxford University Press.

46. Tepper, R. (2012) 'World's meat consumption: Luxembourg eats the most per person, India the least', The Huffington Post, 4 May 2012, http://www.huffingtonpost.com.

47. Tey, Y. S., Shamsudin, M. N., Mohamed, Z., Abdullah, A. M., and Radam, A. (2010) Demand analysis of meat in Malaysia. J. Food Prod. Market. 16, 199-211.

48. Thakrar, R. (2007) Japanese warm to real curries and more. Japan Times. Retrieved 2007-04-23.

49. Thammi Raju, D. and Suryanarayana, M. V. A. N. (2005) Meat consumption in Prakasam district of Andhra Pradesh: an analysis. Livestock Res. Rural Dev. 17.

50. The Times of India (2013) Available from: http://timesofindia.indiatimes.com/india/Beef-exports-up-44-in-4-years-India-is-top seller/articleshow/19314449.cms

51. UNFAO, Meat Consumption per person, 2007, UN FAO.

52. USDA (2013) United States Department of Agriculture Foreign Agricultural Service Approved by the World Agricultural Outlook Board/USDA November 2013.

53. United States Department of Agriculture (USDA) (2013) Foreign Agricultural Service. Livestock and Poultry: World Markets and Trade.

54. van der Mensbrugghe, D., Osorio-Rodarte, I., Burns, A., and Baffes, J. (2011) Macroeconomic Environment and Commodity Markets: A Longer Term Outlook, paper for Expert Meeting on How to Feed the World in 2050, FAO, Rome, 24-26 June 2009, Chapter 5 in Conforti, P., ed. 2011.

55. Wing, E. S. (2000) "Animals used for food in the past: As seen by their remains excavated from archeological sites," in. Kiple, K. F and Ornelas K. C. (eds.), the Cambridge World History of Food. Cambridge, Cambridge University Press, pp. 51-58.

56. Yadav, Yogendra; Sanjay Kumar (2006) "The food habits of a nation." hinduonnet.com (The Hindu). Retrieved 2007-0421.

(Received 2014.4.29/Revised 2014.6.28/Accepted 2014.7.24) 